\title{
Abortion and multifetal pregnancy reduction: An ethical comparison
}

\author{
Silje Langseth Dahl, ${ }^{a}$ Rebekka Hylland Vaksdal, ${ }^{\mathrm{b}}$ \\ Mathias Barra, ${ }^{\mathrm{c}}$ Espen Gamlund, ${ }^{\mathrm{d}}$ Carl Tollef Solberg ${ }^{\mathrm{e}}$
}

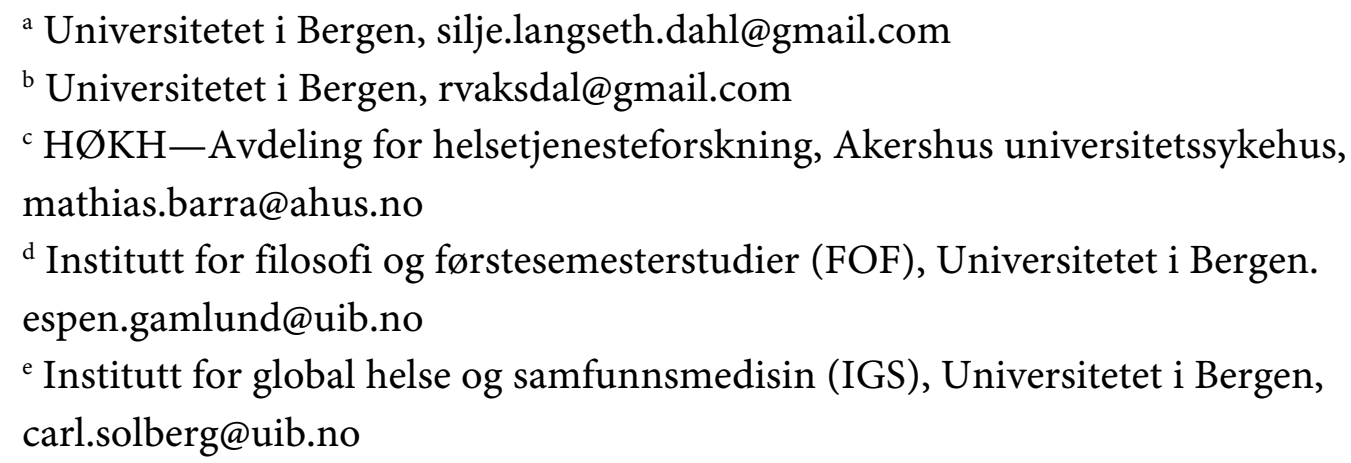

This is an English translation of Dahl, S.. L., Vaksdal, R. H., Barra, M., Gamlund, E., \& Solberg, C. T. (2019). Abort og fosterreduksjon: En etisk sammenligning. Etikk i Praksis - Nordic Journal of Applied Ethics, 13(1), 89111.

DOI: http://dx.doi.org/10.5324/eip.v15i1.3980

(cc) BY

This is an open access article distributed under the terms of the Creative Commons Attribution 4.0 International License, which permits unrestricted use, distribution, and reproduction in any medium, provided the original author and source are credited.

In recent years, multifetal pregnancy reduction (MFPR) has increasingly been a subject of debate in Norway. The intensity of this debate reached a tentative maximum when the Legislation Department delivered their interpretative statement, Section 2 - Interpretation of the Abortion Act, in 2016 in response to a request from the Ministry of Health (2014) that the Legislation Department consider whether the Abortion Act allows for MFPR of healthy fetuses in multiple pregnancies. The Legislation Department concluded that the current abortion legislation [as of 2016] allows for MFPR subject to the constraints that the law otherwise stipulates. The debate has not subsided, and during autumn 2018 it was further intensified in connection with the Norwegian Christian Democratic "crossroads" policy and signals from the Conservatives to consider removing section $2.3 \mathrm{c}$ and to forbid MFPR.

Many of the arguments in the MFPR debate are seemingly similar to arguments put forward in the general abortion debate, and an analysis to ascertain what distinguishes MFPR from other abortions has yet to be conducted. The aim of this article is, therefore, to examine whether there is a moral distinction between abortion and MFPR of healthy fetuses. We will cover the typical arguments emerging in the debate in Norway and exemplify them with scholarly articles from the literature. We have dubbed the most important arguments against MFPR that we have identified the harm argument, the slippery-slope argument, the intention argument, the grief argument, the long-term psychological effects for the woman argument, and the sorting argument. We conclude that these arguments do not measure up in terms of demonstrating a morally relevant difference between MFPR of healthy fetuses and 
other abortions. Our conclusion is, therefore - despite what several discussants seem to think - that there is no morally relevant difference between the two. Therefore, on the same conditions as we allow for abortions, we should also allow MFPR.

Keywords: abortion, ethics, medical ethics, MFPR, selective MFPR

\section{Introduction}

The right to self-determined abortion has been recognised in Norway since 1976 (Abortloven 1976), but it is still a subject of debate (Austveg 2017). Notwithstanding, the right to self-determined abortion before the end of the $12^{\text {th }}$ week of pregnancy is more or less accepted (Pew Research Center 2018), although an increasing number of voices are calling for a tightening of the legislation (Menneskeverd, Kristelig folkeparti 2018 (the Christian Democratic Party), Solberg 2018). In recent years, MFPR has increasingly been a subject of debate in Norway. The intensity of this discussion reached a tentative climax when the Legislation Department delivered its statement, Section 2 - Interpretation of the Abortion Act, in 2016 as a response to the Ministry of Health's [2014] request addressed to the Legislation Department for an interpretation of whether "the Act of 13 June 1975 on Termination of pregnancy (hereinafter Abortion Act) allows for MFPR of healthy fetuses in cases of multiple pregnancies." (Lovavdelingen 2016). The legislation Department refers to historical documents (NOU1991:6, Ot.prp.35) in their reply and concludes:

The Abortion Act allows multifetal pregnancy reduction within the limits the law otherwise stipulates. This means that it is legal to grant multifetal pregnancy reductions on healthy fetuses on the basis of the woman's health, cf. the Abortion Act (medical indication) or on the basis of her situation, ref. Abortion Act $\$ 2$, third section, letter b (social indication) or letter a, or a combination of these grounds. There is also no basis for excluding cases where multifetal pregnancy reduction occurs before the end of the $12^{\text {th }}$ week of gestation on the basis of self-determination, cf. Abortion Act $\$ 2$, second section. Our interpretation is based on the assumption that multifetal pregnancy reduction is carried out so that the selection is random, and that there is no selection between fetuses on a basis other than those which the Abortion Act allows for, ref. 2, section 3, letter c.

The debate has not subsided, and MFPR together with the Abortion Act's section $2.3 c$ - which allows abortion when the fetus is unhealthy - are central to the discussion (Sørvig 2017, Menneskeverd, Barra \& Augestad 2016, Clemet 2018, Saugstad 2018). We have seen comprehensive involvement and discussions marked by legal, medical, and ethical argumentation. However, many of the ethical arguments pertaining to MFPR are similar to the arguments applicable to the right to abortion itself. What is the debate really about? It is unclear whether MFPR is a topic that is inextricably linked to the discussion on abortion, or whether MFPR is a special and separate debate.

We therefore pose the following question in this article: Is there any morally significant distinction between abortion and MFPR on healthy fetuses? We explain what MFPR is, presenting the background for the Norwegian debate, and consider pertinent legislation in some of the other Nordic countries. We then discuss the 
main ethical arguments for and against MFPR. Finally, we conclude that there is no relevant moral difference between abortion and MFPR on healthy fetuses.

\section{Multifetal pregnancy reduction}

$M F P R$ reduces the number of fetuses in multiple pregnancies, e.g., from three to two, or from two to one fetus; experts often refer to " 3 -to-1" or "4-to-2" reductions when this level of precision is required. The procedure, which is currently regarded as permitted ${ }^{1}$ under Norwegian law (Lovavdelingen 2016), is performed by injecting potassium chloride into the fetal heart via an ultrasoundguided puncture through the mother's abdomen, uterus, and fetal membranes. Nonselective MFPR chooses the fetus that is most accessible. The procedure is not possible on monochorionic pregnancies (identical twins sharing a placenta; Evans, MI, Andriole, Evans, SM \& Britt 2015: 97). MFPR is best carried out between gestation weeks nine and fourteen (Mark Evans, personal correspondence, Zemet et al. 2018:94). In Norway, the term nonselective MFPR is used for the reduction of the number of fetuses in a pregnancy with apparently healthy fetuses, while the term selective MFPR (or selective feticide) is used for MFPR on a fetus based on findings from prenatal diagnostics, and for such cases, section $2.3 \mathrm{c}$ is relevant. We will mainly discuss the ethical aspects of nonselective MFPR but will also bring in selective MFPR when relevant.

\section{MFPR in Norway}

MFPR is first mentioned in official documents in [the governmental white paper] NOU1991:6 Biotechnology, authored by the Skjæraasen Committee. It states that:

[B]y selective [MFPR] we understand the practice of reducing the number of fetuses in the uterus by ensuring that one or more of the fetuses die, while the others develop. This can theoretically be applicable to both natural multiple pregnancies and those resulting from IVF treatment. The Commission believes it should not be permitted to perform selective [MFPR] in these cases. This question is not currently regulated in the Act on Abortion (NOU1991:6, p.5).

The Legislation Department of the then Norwegian Ministry of Health and Social Affairs wrote about MFPR in a letter dated $19^{\text {th }}$ of December 2000 (Lovavdelingen 2000). They concluded that an abortion panel may grant MFPR if one or more fetuses have a condition that would otherwise give grounds for abortion during singleton pregnancy, cf. Abortion Act section 2.3c, related to abortions after 12 weeks' gestation. This statement thus concerns selective MFPR. Reduction of healthy fetuses, i.e., nonselective MFPR, was not discussed in this report. However, reference is made to NOU1991:6, and the Legislation Department clearly distances itself from the Skjæraasen Committee's reading of the Abortion Act.

The Norwegian Abortion Act of 1976 deals with the right to abortion. Section 2 of the Act says that if:

[a] pregnancy [leads] to serious difficulties for a woman, she should be offered information and guidance on the assistance which the community can offer her. The woman is entitled to counsel for being able to make her final choice. Finding that the woman, after she has been offered guidance [...] still cannot carry the pregnancy to term, she makes the final decision about abortion 
unless the procedure cannot take place before the end of the twelfth week of pregnancy and there are solid medical reasons for not doing so. After the end of the twelfth week of pregnancy, abortion can be granted, subject to an abortion panel, and only on the basis of especially weighty reasons. (The Abortion Act 1976).

In April 2014 the Norwegian Ministry of Health and Social Affairs asked the Legislation Department to assess whether the Abortion Act allows for MFPR of healthy fetuses, also based on subsection a and/or b (medical and/or social indication) of section 2.3 of the Abortion Act. In February 2016 the Legislation Department concluded that MFPR should be allowed within the constraints laid out in the Abortion Act. This interpretation was explicitly conditional on the assumption that MFPR is performed by random selection of the fetus to be terminated, and that there should be no selection between fetuses on any basis other than the criteria stipulated in the Abortion Act. The decision consequently meant that the woman herself may decide whether to have an MFPR procedure up until the end of the twelfth week of pregnancy, and that granting the procedure at any later stage of gestation must follow the general criteria that apply to other secondtrimester abortions. This prevents selection based on factors such as gender (Lovavdelingen 2016) and means that both selective and nonselective MFPR are to be considered as lawfully regulated by the currently applicable Abortion Act.

Foreign women residing in Norway may undergo an MFPR during their stay in Norway, provided they are in the country at the time of application. All persons residing in Norway are entitled to health care if the provision of health care cannot be postponed, and abortions fall within this category. The general rule is that women who are non-citizens of Norway must pay out-of-pocket for the procedure (Helsedirektoratet 2014).

Forty-eight MFPRs were performed at St. Olav's Hospital and The National Hospital (Rikshospitalet) between 2002 and the time of the Legislation Department's interpretation in the spring of 2016. MFPR was centralised to the National Treatment Service for Advanced Invasive Fetal Medicine (NSFM) in Trondheim, Norway. Since 2016, 41 MFPRs have been performed by the national centre, 13 of which were selective MFPRs. Both selective and nonselective reductions have been carried out on twin, triplet, and quadruplet pregnancies ${ }^{2}$. No foreign patients have undergone MFPR in Norway. There have been requests to do so, but these have been rejected because the women were not present in the country at the time of the application (i.e. women tried to obtain an appointment from their country of residence). The number of cases with complications or miscarriages of the remaining fetuses is unknown due to restrictions set by the Data Protection Officer (Nasjonal behandlingstjeneste for avansert invasiv fostermedisin 2016, 2017, Chief Birgitte Heiberg Kahrs, personal correspondence).

\section{MFPR in the Nordic countries}

The practice and the legal aspects of MFPR in the Nordic countries differ somewhat. Norway is the only Nordic country in which the government has concluded that MFPR is allowed on par with abortion. Denmark is the only Nordic country that has adopted separate legislation for MFPR. The Danish act of 2005 allows MFPR if the procedure can be completed by the end of the twelfth week of pregnancy and if, in addition, one of the following three conditions is met: a) the 
pregnancy poses a serious danger to the mother's life or health, b) MFPR reduces the risk that the pregnancy will result in a miscarriage of all fetuses, or c) one or more fetuses will be unviable or will suffer from a serious illness as a result of premature birth. After the twelfth week of pregnancy, the procedure can take place only if the requirements of MFPR are met, and a competent tribunal approves the petition (Sundhedsloven 2005, sections 92-96). According to the Danish legislation, MFPR is permitted only if the woman is carrying three or more fetuses. It is not permitted to perform MFPR on twin pregnancies in Denmark unless there are specific circumstances (Retsinformation 2006).

Sweden, like Norway, has not introduced separate legislation for MFPR. The Swedish Abortion Act permits abortions before the end of the $18^{\text {th }}$ week of pregnancy (Abortlag 1974 section 1). The Swedish National Council on Medical Ethics (Statens medicinsk-etiska råd) has twice, in 2005 and in 2017, recommended that the government should introduce specific regulations for MFPR in the Swedish Abortion Act (Statens medicinsk-etiska råd 2005, Statens medicinsk-etiska råd 2017). Despite this recommendation, MFPR is presently not explicitly addressed in the legislation, but the procedure is performed in Sweden both for medical and social indications, and The Swedish National Council on Medical Ethics concluded that MFPR should be permitted under the same conditions as other abortions (Statens medicinsk-etiska råd 2017).

In Finland, women wanting an abortion must apply to a panel for permission. Depending on the reasons provided by the applicant, the signature of one, two, or three doctors is required to obtain permission for the procedure. MFPR is not mentioned by the legislation but can be applied for under the same conditions as for abortion (Förordning om avbrytande av havandeskap 1970).

\section{Discussion}

Likely, people who oppose abortion will also oppose MFPR. Furthermore, it is reasonable to imagine that those who argue that MFPR is morally permissible will likewise argue that abortion is morally acceptable. Still, not everyone who endorses abortion will also endorse MFPR. We examine the extent to which it seems reasonable that endorsement of abortion on healthy fetuses should logically entail endorsement of the right to MFPR on healthy fetuses.

\section{The fetus' moral status}

Although we have not seen arguments directly related to the fetus' moral status in the MFPR debate, we want to devote some space to this subject because the view on moral status can influence the discussion of the various arguments. Questions regarding the fetus' moral status and fetal rights have been raised throughout the lengthy debate on abortion, and there is no general consensus on this contested issue. A diversity of values and views, as well as religious and moral perceptions, is presented (Chervenak, McCullough \& Wapner 1992: 84). Some philosophers have argued that abortion is morally unacceptable because it robs the fetus of its future, in the same way as one deprives a child of his/her future by killing the child (e.g. Marquis 1989: 183). Other philosophers have concluded that although a fetus certainly has the potential to become a human being, it nevertheless has no right to life in the fetal stage - no right, that is, that trumps the woman's right to protect her health, freedom, and life (e.g. Warren 1973: 43). In addition, there are those who 
believe that the fetus does not have an independent moral status, but rather a dependent moral status, which is directly linked to the woman's autonomy (e.g. Chervenak et al. 1992: 84).

In the Norwegian Abortion Act, the woman's right to self-determination already ranks above the fetus' right to life. This right to self-determination applies equally to single and multiple pregnancies, as the woman herself may choose to terminate a pregnancy before the end of the twelfth week regardless of how many fetuses she is pregnant with. It is hard to justify that fetuses in a multiple gestation should enjoy a higher (or lower) moral status than the fetus of a singleton gestation. Instead, it is natural to think that fetuses in both single and multiple pregnancies have equal status and rights. It is therefore unnecessary, in our view, to focus on the fetus' moral status for our discussion. Whatever moral status you choose to confer on a fetus, it should be the same for singletons and fetuses of multiple gestations, and we are unaware of anyone arguing otherwise.

\section{Arguments against MFPR}

In the following, we will look at the arguments that advocate against MFPR and suggest that there is a morally relevant difference between abortion and MFPR. We will discuss the harm argument, the slippery-slope argument, the intention argument ${ }^{3}$, the grief argument, long-term psychological effects for the woman, and the sorting argument.

\section{The harm argument}

In the debate on MFPR there is one argument in particular that is recurrent, and that we have chosen to call the harm argument (Clemet 2016, Henden 2016b, Nilsen 2016, Rognsvåg and Weiby 2016, Saugstad 2016b). The harm argument asserts that MFPR is morally unacceptable because it involves a risk of harm to the remaining fetuses, and in the Norwegian debate it is mainly the risk of miscarriage that has been in focus. It is widely accepted that those who intend to bring a new person into the world have a great responsibility for the health of that future person, even among those who do not ascribe a moral status to the fetus. In practice, this is expressed as the mother-to-be's duty not to smoke, drink alcohol, or use other teratogenic drugs during pregnancy (Woollard 2016: 126).

Various views on the fetus' moral status can lead to a different weighting of the various risks inherent in MFPR, and this might influence how the risk of a miscarriage and loss of a remaining fetus should be weighted. If one deems that the fetus deserves a certain minimum degree of legal protection, this will probably weigh heavily. However, in a real situation where the only risk for the remaining fetus is a possible miscarriage, this argument would not be of particular importance since the woman can decide on such a calculated risk for herself, given that proper information is provided to her (Østborg 2016).

The risk of harm to any remaining fetus that will survive until birth, however, will probably weigh very heavily irrespective of what position one takes on a fetus' moral status. When Mark Evans, among others, developed MFPR in the early 1980s, most of the interventions were performed in week 9 and 10, but also earlier. In the early 1990s, there was a concern that very early MFPRs (6-7 weeks) might result in an increased risk of malformations of the extremities of the remaining fetuses, and to err on the safe side MFPRs were not performed prior to weeks 12-14 for a period 
of time. Today, it is regarded as safe to perform MFPRs from 10.5 weeks (Evans, personal correspondence), and the research is relatively clear on MFPRs being beneficial for the remaining fetuses in terms of risk of harm (Evans et al. 2004, Evans \& Britt in 2010, Evans et al. 2015). One under-communicated aspect in the [Norwegian] debate is that for multiple pregnancies of more than two fetuses it is routine to consider MFPR, because of the benefits for the remaining fetuses (considering prematurity and all it entails) are indisputable.

An estimate that has been prevalent in the [Norwegian] debate is that MFPR carries a procedure-related risk of about $15 \%$ for a spontaneous miscarriage of the remaining fetus(es) (Helsedirektoratet 2014, Nilsen 2016). This estimate, however, is one that Torbjørn Moe Eggebø at the National Center for Fetal Medicine (NSFM) presented ahead of a meeting with the Directorate of Health in 2014 and is based on a scenario in which inexperienced Norwegian doctors perform the procedure (Eggebø, personal correspondence). However, no reliable scientific evidence for this figure appears to exist; on the contrary, there is evidence of benefits (Salvesen 2016, Evans 2016). It has also been argued that there are no documented beneficial medical effects from 2-to-1 reductions. Mark Evans has strongly challenged this view in Dagens Medisin (a Norwegian medical newspaper;Evans 2016) ${ }^{4}$.

When discussing the risks associated with MFPR, it is necessary to compare the underlying risk, i.e. the risks associated with multiple pregnancies in itself. For the mother, multiple pregnancies involve risks that include the danger of suffering gestational diabetes, hypertension, and preeclampsia (Santana et al. 2016: 631). For the fetuses of multiple pregnancies, studies have found an increased risk of miscarriage, preterm birth, and low birth weight (Cheong-See et al. 2016: 354). Prematurity and low birth weight, in turn, entails an increased risk of cerebral palsy (McClimmans 2010: 295). Morbidity and mortality increase significantly with the number of fetuses, and it is established that when quadruplets or triplets are reduced to twins, the total risk and the outcomes for both mother and fetus are almost identical to those found in ordinary twin pregnancies (Evans \& Britt 2010: 295, Gupta, Fox, Feinberg, Klauser, Rebarber 2015 580e1-5, Stone et al. 2008: 406e1e4, Evans et al. 2015).

A number of studies to assess the risks associated with MFPR have been carried out. The American professor Mark Evans developed the MFPR procedure that is currently used in Norway (KCl-injection), and he has performed several thousand such interventions. Evans has studied the implications of MFPR ever since the first interventions were performed in the United States in the early 1980s. He has found that a reduction of triplets to twins reduces the risk of miscarriage from $15 \%$ to $4 \%$, from triplets to a singleton from $15 \%$ to $6 \%$ and from twins to a singleton from $8 \%$ to $3 \%$. In addition, Evans found that the mean gestational age following a 3-to-1 reduction improves compared to following 3-to-2 reductions, and that the incidence of birth weight below 1500 grams is ten times higher for 3-to-2 reductions compared to 3-to-1 reductions (Evans \& Britt 2010). Thus, a reduction of triplets to twins is most beneficial in terms of mitigating the risk of miscarriage, but a reduction of triplets to a singleton would be most beneficial in terms of avoiding harm to the remaining fetus (Evans \& Britt 2010). In Norway, we admittedly have very good outcomes for twin pregnancies, meaning that the risk reduction estimates from foreign studies cannot be assumed to be directly applicable to Norwegian conditions. Nevertheless, in a major scientific article from 
2014 that summarises 25 years of experience with MFPR and compares the results from 70 research papers, Evans concludes: 'If one's definition of success is a healthy mother and healthy family, for both morbidity and mortality, the data show conclusively with multiples, fewer is always better. (Evans, Andriole \& Britt 2014: 69). One might infer that Mark Evans, in drawing this conclusion, is normatively recommending that a woman who is pregnant with multiple fetuses should always have an MFPR, but this is not so clear (Evans, Andriole \& Britt 2014: 69, Evans, Kaufman, Urban, Britt \& Fletcher 2004: 102, Evans et al. 2015). It would seem that the facts allow some to perceive MFPR as an opportunity to improve the health of both the woman and the surviving newborns, while others can argue that MFPR is harmful because it causes the miscarriage of one or more fetuses.

In this context, it is appropriate to remark that if MFPR should not be allowed, a woman pregnant with multiple fetuses can only choose "all or none". Presented with a twin pregnancy, it can be assumed that many who want children, but planned for only one more, may choose to continue the pregnancy rather than choose a full termination of the pregnancy; for example, on the basis that they think the risk of miscarriage for the remaining fetus is unnecessarily high. If, however, a woman who wants children still considers it as an impossibility or too risky to carry all the fetuses to term, one cannot rule out that her choice will fall on an abortion. In this situation, the risk of a miscarriage of the remaining fetus(es) after MFPR is small compared with the $100 \%$ certain outcome associated with the abortion of all the fetuses.

Overall, we consider the harm argument inadequate for defending the position that MFPR is morally unacceptable, as there is evidence of neither harm to the remaining fetuses nor for a real increase in the total risk of miscarriage. As we have noted, it is especially the first type of risk - of harm to surviving fetuses - that would be relevant to discriminate between abortion and MFPR.

\section{The slippery-slope argument}

Ola Didrik Saugstad, professor emeritus of paediatrics at the University of Oslo, has argued that MFPR leads to 'extreme sorting'. The reason for this is that one can obtain information about diseases, characteristics, and congenital conditions of the fetus before the end of the twelfth week of pregnancy. He points to the possibility that someone in the future will be able to choose to abort a fetus on the basis of characteristics such as gender, sexual orientation, or skills (Saugstad 2016a, Saugstad 2016b). However, it is the case in Norway that prenatal diagnosis regardless of whether it is a singleton or a multiple pregnancy - is offered to women with risk-pregnancies, such as women above the age of 38 years, or at increased risk of chromosomal abnormalities (Røe, Salvesen \& Eggebø 2012). One can imagine that Saugstad's statement is rooted in a fear of a slippery-slope effect associated with the use of prenatal diagnosis. A slippery slope argument is premised on a belief that the implementation of a relatively moderate proposals may start a chain of events that ultimately leads to an ethically undesirable outcome (Haigh, Wood \& Stewart 2016:819).

Self-determined MFPR, by random selection, is not an exceptional case in this respect. Conditional on the practice that it is the most accessible fetus that is terminated and without prior diagnostics, it is difficult to see that this would be of significance for the development towards further 'sorting' of fetuses. On the other 
hand, for selective MFPR, motivated by severe fetal anomalies, it is difficult to point to any relevant differences between MFPR and the criteria applied to selfdetermined abortions. With MFPR, however, one should note the performing obstetrician's fear of aborting 'the wrong fetus'. Professor Kjell A. Salvesen writes in an OpEd that ' $[\mathrm{I}] \mathrm{t}$ would be tragic to perform a nonselective MFPR at 10-11 weeks, and two weeks later discover that the surviving twin is seriously ill' (Salvesen 2016). In 2016 an MFPR was performed where the remaining fetus after birth proved to have trisomy 21 (Nasjonalt senter for invasive fostermedisin 2016). Salvesen's argument is of some importance, and points to a practice in which random MFPR's do not, in fact, take place and will in any case be postponed until after week 12. Notwithstanding, new NIPT tests provide more accurate test results than ever before, well in advance of week 12, and when fetal anomalies are confirmed, the more relevant debate concerns subsection $2.3 \mathrm{c}^{5}$ more than MFPR (Barra 2016, Abortloven 1976, section 2.3c). In such cases, the risk of miscarriage increases slightly for the remaining fetus, because the procedure - as Salvesen points out - is riskier if the least accessible fetus is selected for termination. Here, we may argue that for pregnant women with two confirmed otherwise healthy fetuses, it is equally conceivable that unselective self-determined MFPR would make active sorting less likely: the evidence of an increased risk associated with not choosing the most accessible fetus for termination provides an independent medical argument in favour of not sorting fetuses based on other characteristics. Nevertheless, it is clear that most people will carry out some fetal diagnostics prior to the procedure, and that any detected anomalies will influence the decisions to be made. Our discussion in this article, is not about such cases.

The fear of a slippery-slope effect leading to increased sorting is understandable, especially if we look at other countries' practices. In the USA, it is permitted to make requests in conjunction with MFPR concerning the desired sex of the fetus the patient wants to retain. For homosexual couples who use surrogate mothers, the woman can transfer eggs fertilised with both fathers' sperm. By reducing the number of fetuses, the fathers can have twins that are biological children of each father (Evans et al. 2015: 97). Sweden allows abortions until the end of the eighteenth week of pregnancy (Abortlag 1974, section 1), and the woman may thus know the fetal sex through routine ultrasound before having an abortion. It also applies in the United States, where some states allow abortions as late as the 24th week of pregnancy (The New York Times 2013). In parts of Asia, sex imbalance is already a fact due to selective abortions of female fetuses. (Ganatra 2008). Still, no one advances the prohibition of self-determined abortion in Norway on the grounds that sex selection occurs abroad.

Furthermore, the slippery-slope argument is not free from problematic aspects. For one, the argument does not take into account that we have the opportunity to manage further development. The medical technology enables many choices that may ultimately lead to fetal sorting. Yet, it does not follow that such choices will be legalised. In addition, the slippery-slope argument assumes that the current drift towards more liberal legislation is undesirable. For many, however, this slope is welcomed, because it means that we allow for more of what is morally desirable. It is not necessary to 'favour abortions' to support this argument; it is possible to be neutral towards abortions, but believe that 'access to reproductive self- 
determination' is a moral good. Our conclusion is therefore that MFPR does not cause - at least not at the present time - a new form of sorting, ${ }^{6}$

\section{The intention argument}

Is it morally permissible that a woman who genuinely wants children has the right to determine the number of children she should have? Some will argue that if the woman desires children, she must accept to have more than she initially planned to have. (Clemet 2016, Det Etiske Råd 2016, Skogedal \& Jemli 2017, NTB 2019). Let us call this the intention argument. Naturally, some will regard this as contradictory. Imagine a woman $A$, who is pregnant with multiple fetuses and who wants to reduce the number of fetuses for no other reason than that she wants fewer children - that is, completely independent of factors such as the risk of mortality and morbidity entailed in carrying a multiple pregnancy to term. She may, for example, have financial concerns. We can compare this woman with woman $B$, a pregnant woman who already has children and who chooses to have an abortion for the same reasons. We thus encounter two pregnant women, both of whom want children, but only a certain number of children, and for the same reasons. Let us further assume that all other factors are equal between woman $A$ and woman $B$. The Abortion Act provides woman $B$ with an option to freely choose this until the end of the twelfth week of pregnancy without having health care professionals or the government secondguessing whether the woman's reasons are valid. Based on this, it is difficult to imagine that woman $B$, who wants an abortion, has a stronger right to decide the number of children she wants to carry to term than woman $A$, who wants an MFPR.

What about a woman who is dependent on in vitro fertilisation (IVF) to conceive? In this case, the woman has expressed a strong desire to have children. Is it therefore wrong to offer her MFPR if the IVF procedure results in a pregnancy with more fetuses than she wants? A study from 1992 examined the outcome of 126 twin pregnancies, where 59 of them were the result of IVF. They found that a total of $29 \%$ of pregnancies resulted in what we may call spontaneous MFPR (vanishing twin) to a singleton and that the rate was the same for the IVF group as for normal pregnancies (Sampson \& Ch. De Crespigny 1992: 107-109). In IVF treatment in Norway, usually only one embryo is transferred to the uterus, and this considerably reduces the likelihood of multiple pregnancy. If the IVF procedure still leads to the woman becoming pregnant with more fetuses than she wants, one can argue that from a welfare-economic perspective it is problematic to first to spend resources to make her pregnant, for next to spend additional resources on reducing the number of fetuses. Here it is natural to compare those costs with the costs associated with multiple pregnancies and morbidity following multiple births. This is a complex calculation which we will not undertake ourselves here, but Mark Evans stated that in 2000 in the USA $57 \%$ of the costs of neonatal care were spent on premature children (Evans \& Britt 2010: 295). Evans asks: '[I]f it is right for a pluralistic society to curb a state's interference with the choice of abortion or other reproductive options, how could it be wrong for society to respect and protect the freedom of couples to choose to have one rather than two infants?' (Evans et al. 2015: 112).

We have already rejected the claim that a fetus of a multifetal pregnancy has higher, or lower, moral status than a singleton. Similarly, it is implausible that the way a fetus is conceived - be it coitus or IVF - should be of relevance for its moral status. We consider it discriminatory to argue that a woman's right to self- 
determination depends on how many fetuses she is pregnant with or how these fetuses have been conceived. On these grounds, it is difficult to see how the intention argument can be significant in terms of assessing whether MFPR is less morally acceptable than other abortions. Even if one assigns weight to the intention argument, it seems that the case of MFPR is poorly suited to enforce such a principle. If we assume that the degree of disadvantage a pregnancy confers on the mother is morally relevant for a decision about an abortion, this concern ought to be in effect also for MFPR.?

\section{The grief argument}

Some of the arguments against MFPR have focused on the remaining child's grief from losing a potential sibling (Hegertun 2016, Kirkeberg and Næsheim 2018, Lund 2018). We choose to call this the grief argument. One can imagine that significant distress will result in a child growing up with the knowledge that he or she might have had a twin. An adult twin has commented that "growing up without my twin sister is completely unimaginable for me", and further, that "if one does away with the one, the other loses a part of herself" (Henden 2016a). It is understandable that a child who has grown up with a twin cannot imagine anything else. But is this any different for a child who has grown up with a non-twin sibling? Also, in this latter case, it appears difficult to imagine a childhood without the sibling.

Henden, following her original opinion piece, was accused of "sentimentalism" and subsequently wrote a second piece in which she presented four points she felt were problematic about MFPR, none of which revolved around the twin bond, or around losing a part of herself (Henden 2016b). Moreover, many of the published opinions [in the Norwegian debate] that promote the grief argument can be interpreted as appeals to prospective parents of twins, where the emphasis is on the joy of being a parent to twins.

To our knowledge, there are no empirical studies on long-term psychological effects for the remaining child following MFPR. In the absence of empirical data, therefore, and in order to compare the trauma of losing a potential sibling via MFPR versus other abortions, we will consider possible scenarios in which the surviving children learn that their parents have had an MFPR or a conventional abortion performed, respectively ${ }^{8}$.

In one scenario, we have a child $A$ who learned during childhood that his parents had an abortion prior to his conception. It is natural that child $A$ may feel grief over the loss of a potential sibling, but it is more difficult to imagine that child $A$ will feel that he has lost a part of himself or his identity, since that part never existed. Child $B$ has instead learned that the parents had an MFPR. The same will apply here: how can $B$ feel that she has lost something she never had? Some will argue that twins have a stronger connection than other siblings (Skoli 2016, Lund 2018). Nevertheless, it is pure speculation to assume that one will miss this association when one has never experienced it. In particular, there is no evidence that those of us who have lost a twin by spontaneous MFPR - which happens in upwards of 30\% of all twin pregnancies (Sampson \& Ch. de Crespigny 1992:107109) - suffer as a result.

However, there are certain differences between child $A$ and child $B$. In the case of child $A$, a phenomenon which in philosophy is often referred to as the nonidentity problem turns up (Parfit 1984). Because the fertilisation processes are of an 
extremely random nature, both in terms of physiological and social aspects, we can conclude with certainty that child $A$ had not existed if the parents had not chosen to carry out a given abortion of a potentially older sibling. They would simply not have conceived the particular child $A$ if they had not had the previous abortion. That is, we could, in fact, not have had other biological older siblings than those we actually have.

In another scenario, we can imagine a child $C$ who learns of an abortion the parents had performed after child $C$ 's birth because they did not want more children. Child $C$ will then have "lost" a potential younger sibling. It makes sense that we could have had other younger siblings than we actually have, and therefore this scenario is a closer analogy to the case of MFPR. But even here it is not very relevant to talk about a child having lost a part of himself or his identity, although one can imagine that child $C$ may be left with a feeling of guilt because she exists at the expense of a completely different individual. That is, child $C$ might imagine that if her parents had aborted her, they could have had another child altogether - child $D$ - instead. But since child $D$ is purely hypothetical and does not exist, nor ever did, it makes little sense that such guilt would have a rational basis. For MFPR, one can imagine that this could lead to even greater grief since it is purely coincidental that precisely child $C$ exists, and another was aborted. However, if MPFR had resulted in the other twin being alive and child $C$ was aborted, then child $C$ would not have existed. The majority of the remaining children after an MFPR will probably prefer living with the thought that they exist at the expense of a potential twin rather than not existing at all. Furthermore, this argument can be extended to abortions. In a society with a right to abortions, such as in Norway, anyone born after 1976 can imagine that their parents could have chosen to have an abortion. We find, therefore, that the grief argument has its flaws, but it cannot be rejected categorically. We do not, however, see any reasons why the grief argument should have substantially more relevance for MFPR than for regular abortions, and conclude that the grief argument therefore cannot be used to distinguish between abortion and MFPR.

\section{Long-term psychological effects for the woman}

It is natural to discuss whether MFPR might entail psychological consequences for the mother, or more generally, for both parents. There have been numerous studies investigating this issue specifically. In one study, it was reported that a third of the mothers experience symptoms of depression and guilt one year after MFPR. These symptoms, however, were largely absent after two years of follow-up. Compared with mothers of triplets who did not undergo MFPR, the MFPR group reportedly had lower levels of anxiety and depression shortly after the procedure, as well as fewer problems linked to psychological attachment to the children born (Garel et al. 1997: 617). Other studies have shown similar results, with some of the women and parents reporting grief, remorse, and feelings of guilt shortly after they had undergone MPFR, but any long-term psychological effects appear to be mild (McKinney, Downey \& Timor-Tritsch 1995: 51, Sentilhes et al. 2008: 295, Schreiner-Engel, Walther, Midnex, Lynch \& Berkowitz 1995: 541). It was also found that women who had had a MFPR performed were not subject to elevated risk of developing depression or other mental disorders compared to pregnant women or new mothers who had not had MFPR (McKinney et al. 1995: 51). All of 93\% of the 
women who participated in one of the studies reported that they would make the same decision on MFPR again in the same situation (Schreiner-Engel et al. 1995: 541).

Several studies have examined the long-term psychological effects on women who undergo an abortion. A study from 2000 reported that two years after having completed the procedure, a majority of the participants reported satisfaction with their decision, and that they would make the same decision again. A majority of the women reported that their abortion provided more positive than negative psychological effects, and that they were not depressed. Furthermore, it was found that most of the women who did report adverse psychological effects following the abortion had been depressed earlier in life (Major, Cozzarelli \& Cooper 2000: 777). A large quantitative meta-analysis from 2011 examined the relationship between abortion and mental health by collecting data from several studies conducted over a period of fourteen years. It was found that, in comparison with pregnant women who had neither wanted nor chosen to have an abortion, women who did choose to have an abortion had a significantly increased risk of developing mental illness. In this study, it was claimed that $5.5 \%$ of the mental illness in this group was directly attributable to the decision to have an abortion (Coleman 2011: 180). When one looks at the more relevant control group - women who wanted an abortion but were not allowed one - the picture is different (Biggs, Upadhyay, McCulloch \& Foster, 2017; Stotland \& Shrestha 2018).

One might raise the question of whether having an MFPR exerts greater mental stress on the woman or the couple than having an abortion does (Evans et al. 2015), or whether an MFPR represents less mental stress insofar as it increases the likelihood of bringing one or more healthy children into the world. The aforementioned studies tell us that both abortions and MFPRs can be experienced as traumatic and stressful for the woman and for the couple shortly after the procedure. Nevertheless, it is reasonable to assume that a woman who may choose between performing MFPR or aborting all fetuses is best served by the former in terms of long-term psychological effects. It is natural to assume that the positive aspects of giving birth to one or more healthy newborns may partly overshadow the negative effects of the loss of one or more of the fetuses. Therefore, it seems unreasonable to cause more mental stress than necessary by offering complete abortions as the only alternative in a situation where the woman, for various reasons, does not want as many children as the number of fetuses she is pregnant with. Consequently, it is natural to think that the risk of negative psychological long-term effects for the woman cannot justify the assertion that MFPR is less morally acceptable than abortion. On the contrary: women who are denied abortions when they want one do suffer, and women who feel compelled to have an unwanted abortion suffer. We see here that the argument from long-term psychological effects can alternatively be seen as strengthening the moral rationale for MFPR over abortions.

\section{The sorting argument}

Some argue that MFPR may not only lead to sorting based on characteristics such as sex and developmental anomalies, but it may also result in a society in which twins will feel discriminated against and generally unwanted (Rognsvåg \& Weiby 2016). We call this the sorting argument. For example, as Saugstad asks: '[...] what 
will MFPR on twins do with our view of human relations in general and of twins in particular?' Moreover, he argues that we need to consider any harm MFPR confers on twins, both those who already exist, and for those who are survivors after such an intervention (Saugstad 2016b). The concern that Saugstad raises can be recognised as a variant of the slippery-slope argument: the acceptance of MFPR will cause a drift towards a generally negative sentiment against multiple births. But is it reasonable to attribute weight to the possibility that twins as a group may feel stigmatised because we have allowed MFPR for twin pregnancies? And is it plausible that we will have a society in which twins [in general] are not wanted?

That MFPR is legally permitted implies neither a moral nor legal obligation to perform the intervention. ${ }^{9}$ The right to abortions has not resulted in children no longer being born in Norway, and the number of abortions in recent years has been fairly stable. In the same way, there is little reason to believe that a majority of women with twin pregnancies will choose to take advantage of MFPR, ultimately leading to a society without twins. Self-determination means that it is up to the woman to decide whether or not to conduct an MFPR until the end of the twelfth week of pregnancy, and that MFPR should be an informed choice based on the woman's own values and preconditions. To put it bluntly, one might argue that if the twins who already exist have reason to feel discriminated against as a result of legalised MFPR, then so does any person born after $1976 .{ }^{10}$

One twin who has participated in the [Norwegian] debate on MFPR argues that if the ultimate consequence of MFPR is a society without twins, it is a sign of more fundamental problems, such as an insufficient level of social benefits for families with twins. He writes that '[...] ultimately it is better that the Abortion Act exists in 30 years, than that twins exist.' (Aastebøl 2016). This can be interpreted as a reverse slippery-slope argument, where Aastebøl fears that prohibiting MFPR in a worstcase scenario may cause abortion legislation to be curtailed or rescinded. It is hard to imagine that the right to abortion will be discontinued after so many years just because a new procedure, which did not exist when the Abortion Act was written, is banned. ${ }^{11}$ On the other hand, it is precisely a form of curtailing of the current legislation, specifically section $2.3 \mathrm{c}$, which has been on the agenda in debates at government level in autumn 2018. The fear of a more conservative policy and the loss of established reproductive rights may be justified, and there appears to be substantial concurrence between those who now call for abandoning $2.3 \mathrm{c}$, those agitating against MFPR, and those who argue for further restrictions on access to abortions. ${ }^{12}$

There is little to suggest that twins will become extinct in Norway as a result of MFPR, and it is up to the politicians to focus on governing the use of MFPR in the same manner as abortions are governed. Moreover, "twinhood" is not a biological attribute of an individual. The fear of depletion of genetic variation, an important component of the general sorting argument, applies only tangentially to the case of MFPR on twins. Twin pregnancies occur regularly. In contrast to e.g., the case of the extensive use of section 2.3c abortions on fetuses with Huntington's - which can result in the gene being eradicated - a possible decrease in twin pregnancies will be reversible. ${ }^{13}$

For these reasons, we argue that the sorting argument cannot be used to defend the position that abortion is more morally permissible than MFPR on healthy twins. 
We maintain that these objections are either weak (the grief and the harm arguments), are veiled anti-abortion (pro-life) arguments (the intention argument), or properly belong in the general debate on abortions (long-term psychological effects for the woman), and that the stronger arguments all belong in the section $2.3 \mathrm{c}$ debate (the sorting and slippery-slope arguments). Overall, we consider that these arguments against MFPR do not indicate that there is a morally relevant difference between self-determined MFPR on healthy fetuses and other selfdetermined abortions, and, that these arguments do not provide a compelling defence for a ban on the procedure.

\section{Arguments in favour of MFPR}

We will now consider arguments in favour of MFPR. We will consider parental autonomy and discuss why selective, section 2.3c indicated, MFPR is not sufficient (to secure basic reproductive rights).

\section{Parental Autonomy}

Respect for autonomy, or self-determination, is one of the key principles of medical ethics (Gillon 2003: 307). Through respect for autonomy, we recognise the patients' right to their own opinions, their own bodies, and their own health, and their right to make choices based on personal values and beliefs. For the decision to have an abortion or an MFPR, it is particularly important that women receive adequate information about treatment options. As a preventive measure, the information must deal with how society can assist her if she chooses to carry the pregnancy to term. This provides the basis for informed consent, which is central to the principle of respect for autonomy (ACOG Committee 2013: 405). When abortion legislation ensures respect for women's autonomy in their decision whether to have an abortion, why should not the same respect be extended to a woman who desires an MFPR intervention? The woman's body, health, life situation, and family are affected to an equal extent. If she feels that it would be too great a burden to bring as many children into the world as the number of fetuses she is pregnant with, she should not be forced to terminate the pregnancy by abortion when we are now able to offer her the choice to retain one or more of the fetuses.

The choice of having an MFPR is not an easy decision to make, in the same way that the choice to have an abortion is not. Summing up after 25 years of experience with MFPR, Evans [and Britt] states that "Fetal reduction of any number is emotionally and morally troubling for couples, even when couples make educated decisions after an extensive consent process" (Evans \& Britt 2010: 300-301). To respect the woman and couple's autonomy does not mean that we impose a decision on them, but rather that we guarantee each woman and couple the freedom to make the choice that is best according to their set of values, religious faith, or personal ethical conviction. We believe that this right and this freedom must be preserved and protected.

\section{Why selective MFPR is not sufficient}

Some will argue that there is a significant moral difference between selective MFPR and MFPR on healthy fetuses. Understandably, the termination of a fetus with severe somatic illness or disorder may be perceived as more morally acceptable than the termination of a healthy fetus. Philosopher Leah McClimmans defends selective 
MFPR, partly on the basis of the lifeboat principle. She compares a multiple pregnancy with a sinking lifeboat carrying more passengers than its authorised capacity, arguing that it may be acceptable to sacrifice some individuals so that all do not perish. She next questions if the force of this argument is weakened when applied to MFPR on healthy fetuses. She argues that it is reasonable to assume that parents who want nonselective MFPR believe that not reducing the number of fetuses would also cause suffering or injury. McClimmans emphasises that it is problematic to use only medical facts and diagnoses to guide ethical decisions. Empirical facts, she argues, are not ethically normative, since they are based exclusively on biological aspects of health (McClimmans 2010: 295).

It is evident that health is a complex concept which, in addition to the biological aspects, also includes mental health, social aspects, and an individual's own perception of their quality of life (WHO 1946). It is common to maintain that what constitutes good health, and what constitute a harm, is partly a matter of subjective opinion, even in the face of objective medical facts to the contrary. Therefore, it would be wrong to conclude that the presence of a somatic disorder is synonymous with poor health or that the absence of suffering is synonymous with good health (McClimmans 2010: 295). If a woman, based on her own assessment of her life situation, considers that carrying a multiple pregnancy to term with all the fetuses will lead to overall poorer health for her and/or the children being born, regardless of whether a somatic disorder is present, it appears clear to us that MFPR may be a good option for her, and hence a choice we as a society should respect. Based on this, it is difficult to argue that the woman's health and life situation are weightier factors in the decision to perform MFPR on anomalous fetuses than when the fetuses are healthy. In our view, the claim that selective MFPRs are morally acceptable, whereas MFPRs on healthy fetuses are not, carries the implication that abortions of healthy fetuses must also be morally unacceptable.

\section{Should MFPR be legal?}

We have demonstrated that none of the objections raised appear significantly more valid for MFPR than for ordinary abortions. In addition, we have highlighted the right to self-determination as an equally important argument in favour of MFPR as it is for self-determined abortion. In Norway, the right to self-determined abortions has been guaranteed by legislation for more than 40 years. It was difficult, of course, to predict that our society eventually would have to take a stance on MFPR when the Abortion Act was drafted, and it is easy to understand that permitting new medical procedures that deal with life and death leads to a new heated debate. Based on our discussion, however, we find no evidence for the proposition that a country with legalised abortion should not also allow MFPR on healthy fetuses ${ }^{14}$.

MFPR has been performed in the United States since the 1980s, and we have pointed to evidence that the procedure employed in Norway does not cause any significantly increased risk of harm to remaining fetuses compared with the risks associated with carrying a multiple pregnancy to term. It is obvious that the procedure requires appropriate training of the physicians who will perform the procedure, just like for any other medical procedure. We consider it reasonable that a relatively small number of physicians should receive training in MFPRs, and that the procedure should be centralised to a national treatment service (Evans 2016). 
Given that Norwegian physicians master the method used for MFPR, we see no reason why this procedure should not be permitted under the same conditions as other self-determined abortions. We have only briefly touched on legislation issues in this article, but it is conceivable that it may be clarifying for some if the Abortion Act was amended to include a separate section explicitly addressing MFPRs.

\section{Conclusion}

The aim of this article was to discuss whether there is any significant moral distinction between abortion and MFPR. First, we considered the arguments against MFPR. We discussed the harm argument, the slippery-slope argument, the intention argument, the grief argument, long-term psychological effects for the woman, and the sorting argument. Then we considered the arguments in favour of MFPR, with an emphasis on parental autonomy and why selective MFPR is not sufficient. Our conclusion is that if abortion is morally permissible, it appears reasonable that MFPR should also be morally permissible. This applies unless there exists compelling research presenting results that establish risks or harm to the remaining fetuses or to the pregnant woman that we have overlooked. Consequently, it seems reasonable that the issue of the moral acceptability of MFPRs turns on whether abortions, in general, are morally acceptable.

\section{Acknowledgements}

Thanks to Mark Evans and Birgitte Kahrs for help with medical evidence, and to two anonymous referees for valuable suggestions which improved the article. We would also like to thank Tim Challman and Gavin for help with this English translation.

\section{Notes}

${ }^{1}$ At the time of proofreading of this article, there is an amendment to the Abortion Act out for public consultation which seeks to ban self-determined MFPR (Ministry of Health and Care Services 2019). The very recent debate and events are also illuminated in footnotes 7 and 11. At the time of this translation to English, the Norwegian Abortion Act has been amended. It now, in 2020, asserts that MFPR is a form of abortion and is regulated by the Abortion Act. It also states that MFPR is not available to women by self-determination, and MFPR cannot be performed without the permission from an abortion panel, regardless of the timing of the procedure. The law furthermore places additional restrictions on 2-to-1 reductions, and effectively prohibit these.

${ }^{2}$ The figures for completed MFPR are valid up to 23 November 2018.

${ }^{3}$ The intention argument includes the imperative "If you can manage one, then you should be able to manage two" (NTB 2019).

${ }^{4}$ And, more recently, again in Dagsavisen April 2019, Evans calls the Norwegian assessment of MFPR 'bullshit'. https://www.dagsavisen.no/innenriks/sabler-neddet-norske-fagmiljoet-1.1468910

${ }^{5}$ The Norwegian Abortion Act's section 2.3c regulates second-trimester abortions on indication of fetal anomaly. 
${ }^{6}$ Some have nevertheless suggested that fetal reduction itself is a form of sorting, since one fetus 'is selected' (Saugstad 2016a). It is a curiosity that the term 'sort' etymologically derives from the Latin "sortiri", meaning 'to choose by lot'. The connotations of the Norwegian word 'sort', however, is in a certain sense the opposite: 'to organise into categories, grouping according to specific criteria'.

7 'If you can manage one, you can manage two' (NTB 2019). In the proposed amendment to the Abortion Act, addressing MFPR, the intention argument is clearly recognisable in phrases about how triplet pregnancies may be reduced to twins, but not to singletons. (MOH 2019).

${ }^{8}$ There are probably many children who will never know that their parents have carried out MFPR or an abortion. It is hard to imagine that this could have an impact on the lives of these children, and therefore such cases are not appreciably relevant to the grief argument.

${ }^{9}$ Although, in the event of a large number of fetuses, e.g., four or more, it can be argued that reducing the number to two is a moral imperative on a par with not smoking or refraining from using drugs, [given the clear and unequivocal benefits of such reductions.]

${ }^{10}$ We recognise that Norwegians born after 1976 are not a minority in society, but that twins are. It is natural to assume that twins may experience that part of their identity is linked with being twins.

${ }^{11}$ We have not argued that there is a necessary relationship between (1) opposing MFPR in healthy fetuses and (2) opposing the right to [selective] abortion on anomalous fetuses (cf. section 2.3c). However, it is an empirical fact that the two major organisations that have spoken out most strongly against MFPR - The Christian Democratic Party and the Human Dignity [Menneskeverd] organisation - also advocate strongly against section $2.3 \mathrm{c}$.

${ }^{12}$ We have not argued here that (1) rejecting MFPR of healthy fetuses and (2) rejecting abortion of abnormal fetuses is causally connected (cf section 2.3c). It remains an empirical fact that the two major [Norwegian] organisations that have advocated the banning of MFPR - KrF and Menneskeverd - also advocate against section $2.3 \mathrm{c}$.

${ }^{13}$ A phenomenon that also applies to chromosomal abnormalities.

${ }^{14}$ The fact that something is permitted does not necessarily mean that it comes with a right attached, and under a priority setting perspective it can, of course, be debatable whether MFPR on healthy twins should be offered (free of charge) on request. There is no doubt that an MFPR is something quite different from a regular abortion and requires a lot more resources and expertise - even if we conclude that the involved ethics are comparable. Besides, we have not discussed how reservation issues come into play, and one can imagine that healthcare professionals might have reservations specifically against participating in MFPRs (just as it is possible to have reservations against participating in abortions today in Norway).

\section{References}

Aastebøl, I. (2016). Ja, så utrydd meg, da! Det er viktigere at abortloven finnes om 30 år, enn at det finnes tvillinger. Aftenposten. https://www.aftenposten.no/meninger/debatt/i/m5vp/Ja_-sa-utrydd-meg_- 
da-Det-erviktigere-at-abortloven-finnes-om-30-ar_-enn-at-det-finnestvillinger--Iver-Aastebol) (Accessed 27 February 2018).

Abortlag. (1974). (1974:595). http://www.riksdagen.se/sv/dokumentlagar/dokument/svenskforfattningssamling/abortlag-1974595_sfs-1974595) (Accessed 12 February 2018).

Abortloven. (1976). Lov om svangerskapsavbrudd (LOV-1975-06-13-50). https://lovdata.no/dokument/NL/lov/1975-06-13-50 (Accessed 12 February 2018).

ACOG Committee. (2013). ACOG Committee opinion no. 553: multifetal pregnancy reduction. Obstetrics \& Gynecology 121(2 Pt 1): 405-410.

Austveg, B. (2017). ABORT en etisk argumentasjon (1. utg.). Oslo: Humanist forlag

Barra, M. \& Augestad, L. A. (2016). Faglige råd i fosterreduksjonssaken. Dagens medisin. https://www.dagensmedisin.no/artikler/2016/04/12/faglige-radi-fosterreduksjonssaken/ (Accessed 28 February 2018).

Biggs, M. A., Upadhyay U. D., McCulloch, C. E. \& Foster D. G. (2017). Women's Mental Health and Well-Being 5 Years after Receiving or Being Denied an Abortion: A Prospective, Longitudinal Cohort Study. JAMA Psychiatry 74(2): 169-178. https://doi.org/10.1001/jamapsychiatry. 2016.3478

Cheong-See, F., Schuit, E., Arroyo-Manzano, D., Khalil, A., Barrett, J., Joseph, K. S., Thangaratinam, S. (2016). Prospective Risk of Stillbirth and Neonatal Complications in Twin Pregnancies: Systematic Review and MetaAnalysis. British Medical Journal 354:i4353. https://doi.org/10.1136/ bmj.i4353.

Chervenak, F. A., McCullough, L. B. \& Wapner, R. J. (1992). Selective termination to a singleton pregnancy is ethically justified. Ultrasound in Obstetrics \& Gynecology 2(2): 84-87. https://doi.org/10.1046/j.14690705.1992.02020084.x

Clemet, K. (2016). Et foster for mye? Civita. https://www.civita.no/2016/02/22/ et-foster-for-mye (Accessed 12 November 2018).

Clemet, K. (2018). Paragraf 2c: Prinsipielt og moralsk viktig. Civita. http://clemet.blogg.no/1541008119_paragraf_2c_prinsipielt_og_moralsk _viktig.html (Accessed 12 November 2018).

Coleman, P. K. (2011). Abortion and mental health: quantitative synthesis and analysis of research published 1995-2009. The British Journal of Psychiatry 199(3): 180-186. https://doi.org/10.1192/bjp.bp.110.0772

Det Etiske Råd. (2016). Det Etiske Råds udtalelse om fosterantalsreduktion. http://www.etiskraad.dk/etiske-temaer/abort-og-

fosterdiagnostik/publikationer/udtalelse-om-fosterantalsreduktion-2016 (Accessed 15 November 2018).

Evans, M. I., Kaufman, M. I., Urban, A. J., Britt, D. W. \& Fletcher, J. C. (2004). Fetal reduction from twins to a singleton: a reasonable consideration? Obstetrics \& Gynecology 104(1): 102-9. https://doi.org/10.1097/01. AOG.0000128299.57908.90

Evans, M. I. \& Britt, D. W. (2010). Multifetal Pregnancy Reduction: Evolution of the Ethical Arguments. Seminars in Reproductive Medicine 28(4):295-302. https://doi.org/10.1055/s-0030-1255177 
Evans, M. I., Andriole, S. \& Britt, D. W. (2014). Fetal reduction: 25 years' experience. Fetal diagnosis and therapy 35(2): 69-82. https://doi.org/ $10.1159 / 000357974$

Evans, M. I., Andriole, S., Evans, S. M. \& Britt, D. W. (2015). Medical Reasons for Pregnancy Interruption: Fetal Reduction. I: J. P. Galst, M. S. Verp (Red), Prenatal and Preimplantation Diagnosis (s. 97-117). New York: Springer. https://doi.org/10.1007/978-3-319-18911-6_5

Evans, M. I. (2016). Uvitenhet - eller feilaktig skråsikkerhet. Dagens medisin. https://www.dagensmedisin.no/artikler/2016/05/13/uvitenhet--ellerfeilaktig-skrasikkerhet/ (Accessed 12 November 2018).

Förordning om avbrytande av havandeskap. (1970). http://finlex.fi/sv/laki/ ajantasa/1970/19700359?search\%5Btype\%5D=pika\&search\%5Bpika\% $5 \mathrm{D}=$ abort (Accessed 12 February 2018).

Ganatra, B. (2008). Maintaining Access to Safe Abortion and Reducing Sex Ratio Imbalances in Asia. Reproductive Health Matters 16(sup31):90-98.

Garel, M., Stark, C., Blondel, B., Lefebvre, G., Vauthier-Brouzes, D. \& Zorn, J. R. (1997). Psychological reactions after multifetal pregnancy reduction: a 2year follow-up study. Human reproduction 12(3): 617-622. https://doi.org/ 10.1093/humrep/12.3.617

Gillon, R. (2003). Ethics needs principles - four can encompass the rest - and respect for autonomy should be "first among equals". Journal of Medical Ethics 29(5): 307-312. https://doi.org/10.1136/jme.29.5.307

Gupta, S., Fox, N., Feinberg, J., Klauser, C.K., Rebarber, A. (2015). Outcomes in twin pregnancies reduced to singleton pregnancies compared with ongoing twin pregnancies. American Journal of Obstetrics \& Gynecology 213(4):580.e1-580.e5. https://doi.org/10.1016/j.ajog.2015.06.018

Haigh, M., Wood, J. S. \& Stewart, A. J. (2016). Slippery slope arguments imply opposition to change. Memory \& Cognition 44(5): 819-836. https://doi.org/ 10.3758/s13421-016-0596-9

Hasson, J., Shapira, A., Many, A., Jaffa, A. \& Har-Toov, J. (2011). Reduction of twin pregnancy to singleton: does it improve pregnancy outcome? The Journal of Maternal-Fetal \& Neonatal Medicine 24(11):1362-1366. https://doi.org/10.3109/14767058.2010.547964

Helsedirektoratet. (2014). Helsedirektoratets vurderinger i forbindelse med fosterreduksjon for abortsøkende kvinner med flerlingesvangerskap. https://helsedirektoratet.no/Documents/Lovfortolkninger/Abortloven/B rev\%20om\%20vurderinger\%20flerlingesvangerskap\%2027032014.pdf (Accessed 8 February 2018).

Henden, A. (2016a). Jeg er for abort, men jeg er også tvilling. Og norsk lov gir meg bakoversveis. Aftenposten. https://www.aftenposten.no/meninger/ sid/i/JEkJ/Jeg-er-for-abort_-men-jeg-er-ogsa-tvillingOg-norsk-lov-girmeg-bakoversveis--Amalie-Henden-22 (Accessed 26 February 2018).

Henden, A. (2016b). Fire problemer med tvillingabort - uten føleri. Aftenposten. Hentet november 25, 2018, fra: https://www.aftenposten.no/meninger/ sid/i/715Xw/Fire-problemer-med-tvillingabort---uten-foleri--TvillingAmalie-Henden

Hegertun, A. (2016). Elvis savnet tvillingbroren sin hele livet. Aftenposten. https://www.aftenposten.no/meninger/debatt/i/4zM6/Elvis-savnet- 
tvillingbroren-sin-hele-livet--Andreas-Hegertun (Accessed 22 November 2018).

Kirkeberg, K.J. \& Næsheim, A.A. (2018). Aftenposten. https://www.aftenposten. no/meninger/sid/i/5VzXmz/Du-hadde-en-tvilling_-og-du-var-

tilfeldigvis-den-som-fikk-leve---Kirkeberg-og-Nasheim (Accessed 22 November 2018).

Kristelig folkeparti. (2018). Sortering og tvillingabort - Hva mener egentlig Krf? https://www.krf.no/nyheter/nyheter-fra-krf/sortering-og-tvillingabort/ (Accessed 5 December 2018).

Lund, S. S. (2018). Jeg kan ikke forestille meg et liv uten tvillingbroren min. Aftenposten. https://www.aftenposten.no/meninger/sid/i/1107nA/Jegkan-ikke-forestille-meg-et-liv-uten-tvillingbroren-min--Solaia-SkogenLund (Accessed 22 November 2018).

Lovavdelingen. (2000). $\$ 2$ - Tolkning av lov av 13. juni $1975 \mathrm{nr} .50 \mathrm{om}$ svangerskapsavbrudd. https://www.regjeringen.no/no/dokumenter/-2--tolkning-av-lov-av-13.-juni-1975-nr.-50-omsvangerskapsavbrudd/id2480549/ (Accessed 9 November 2018).

Lovavdelingen. (2016). $\$ 2$ - Tolkning av abortloven. https://www.regjeringen. no/no/dokumenter/-2---tolkning-avabortloven/id2476193/ (Accessed 8 February 2018).

Major, B., Cozzarelli, C. \& Cooper, M. (2000) Psychological Responses of Women After First-Trimester Abortion. Archives of General Psychiatry 57(8): 777784. https://doi.org/10.1001/archpsyc.57.8.777

Marquis, D. (1989). Why abortion is immoral. The Journal of Philosophy 86(4): 183-202. https://doi.org/10.2307/2026961

McClimmans, L. (2010). Elective twin reductions: evidence and ethics. Bioethics 24(6): 295-303. https://doi.org/10.1111/j.1467-8519.2008.01704.x

McKinney, M., Downey, J. \& Timor-Tritsch, I. (1995). The psychological effects of multifetal pregnancy reduction. Fertility and Sterility 64(1): 51-61. https://doi.org/10.1016/S0015-0282(16)57654-7

Menneskeverd. Tema: Abort. https://www.menneskeverd.no/tema/abort/ (Accessed 21 November 2018).

Nasjonal behandlingstjeneste for avansert invasiv fostermedisin. (2016). Årsrapport. https://forskningsprosjekter.ihelse.net/senter/rapport/NBHMN-01/2016 (Accessed 26 November 2018).

Nasjonal behandlingstjeneste for avansert invasiv fostermedisin. (2017). Årsrapport. https://forskningsprosjekter.ihelse.net/senter/rapport/NBHMN-01/2017 (Accessed 26 November 2018).

Nilsen, L. (2016). Frykter konsekvensene av fosterreduksjon. Dagens Medisin. https://www.dagensmedisin.no/artikler/2016/02/18/frykterkonsekvensene-avfosterreduksjon (Accessed 28 February 2018).

NOU 1991: 6. (1990). Mennesker og bioteknologi. https://www.regjeringen.no/ globalassets/upload/kilde/odn/tmp/2002/0034/ddd/pdfv/154784nou1991-6.pdf (Accessed 9 November 2018).

Parfit, D. (1984). Reasons and Persons. New York: Oxford University Press.

Pew Research Center. (2018). 6. Religion and society. http://www.pewforum.org/ 2018/05/29/religion-and-society/ (Accessed 15.12.20). 
Retsinformation. (2006). Vejledning om svangerskabsafbrydelse og fosterreduktion, 3. Tilladelig fosterreduktion. https://www.retsinformation.dk/ Forms/R0710.aspx?id=10239 (Accessed12 February 2018).

Rognsvåg, S. \& Weibye, T. (2016). KrF og Sp ber Høie forby tvillingaborter. Dagen. http://www.dagen.no/Nyheter/FOSTERREDUKSJON/KrF-ogSp-ber-Høie-forbytvillingaborter-308444 (Accessed 28 February 2018).

Røe, K., Salvesen, K. Å. \& Eggebø, T. M. (2012). Blir retningslinjene for fosterdiagnostisk ultralyd fulgt? Tidsskrift for Den norske legeforening 132(14): 1603-6.

Salvesen, K.Å. (2016). Selvbestemt fosterreduksjon av tvillinger. Dagens Medisin. https://www.dagensmedisin.no/artikler/2016/04/04/selvbestemt-foster-reduksjon-av-tvillinger/ (Accessed 15 November 2018).

Sampson, A. \& Ch. De Crespigny, L. (1992). Vanishing twins: the frequency of spontaneous foetal reduction of a twin pregnancy. Ultrasound in Obstetrics \& Gynecology 2(2): 107-109. https://doi.org/10.1046/j.14690705.1992.02020107.x

Santana, D. S., Cecatti, J. G., Surita, F. G., Silveira C., Costa, M. L., Souza, J. P.,... Vogel, J. P. (2016) Twin Pregnancy and Severe Maternal Outcomes: The World Health Organization Multicountry Survey on Maternal and Newborn Health. Obstetrics \& Gynecology 127(4): 631-641. https://doi.org/10.1097/AOG.0000000000001338

Saugstad, O. D. (2016a). Fosterreduksjon åpner for ekstrem sortering. Morgenbladet. https://morgenbladet.no/ideer/2016/02/fosterreduksjonap ner-ekstrem-sortering (Accessed 28 February 2018).

Saugstad, O. D. (2016b). Fosterreduksjon er inhumant. Tvillingreduksjon åpner for ekstrem sortering. Aftenposten https://www.aftenposten.no/ meninger/debatt/i/oaM77/Fosterreduksjon-erinhumantTvillingreduksjo n-apner-for-ekstrem-sortering--Ola-Didrik-Saugstad (Accessed 27 February 2018).

Saugstad, O. D. (2018). Abort og Verdier. Vårt Land. http://www.verdidebatt.no/ innlegg/11729647-abort-og-verdier (Accessed 12 November 2018).

Schreiner-Engel, P., Walther, V. N., Midnex, J., Lynch, L. \& Berkowitz, R. L. (1995). First-trimester multifetal pregnancy reduction: Acute and persistent psychologic reactions. American Journal of Obstetrics \& Gynecology 172(2): 541-547. https://doi.org/10.1016/0002-9378(95)905707

Sentilhes, L., Audibert, F., Dommergues, M., Descamps, P., Frydman, R., Mahieu-Caputo, D. (2008). Multifetal pregnancy reduction: indications, technical aspects and psychological impact. La Presse Médicale 37(2): 295-306. https://doi.org/10.1016/j.lpm.2007.05.016

Skogedal, M. \& Jemli, N. (2017). Tvillinger langer ut mot fosterreduksjon: Hvem av oss skal bort? Stavanger Aftenblad. https://www.byas.no/ aktuelt/i/eQK6g/Tvillinger-langer-ut-mot-fosterreduksjon--Hvem-avoss-skal-bort (Accessed 22 November 2018).

Skoli, S. (2016). Vi tvillingmødre vet at våre tvillinger er knyttet sammen på et nivå selv ikke vi kan forstå. Dagen. https://www.dagen.no/ dagensdebatt/samfunn/TVILLINGABORT/Vi-tvillingmødre-vet-at-våre -tvillinger-er-knyttet-sammen-på-et-nivå-selv-ikke-vi-kan-forstå-

308687 (Accessed 22 November 2018). 
Solberg, E. (2018). Grensen mot sorteringssamfunnet. Ernas blogg. https://erna.no/2018/10/19/grensen-mot-sorteringssamfunnet/

(Accessed 5 December 2018).

Sosial- og helsedepartementet. (2001). I-42/2001. https://www.regjeringen.no/ no/dokumenter/i-422001/id108956/?q=fosterreduksjon (Accessed 8 February 2018).

Statens medicinsk-etiska råd. (2005). Yttrande angående s.k. fosterreduktion. http://www.smer.se/skrivelser/yttrande-angaende-s-kfosterreduktionert-dnr-s20045253hs/ (Accessed 12 February 2018).

Statens medicinsk-etiska råd. (2017). Reduktion av antal foster. http://www.smer.se/smer-kommenterar/smer-kommenterar20171reduktion-av-antalet-foster/ (Accessed 12 February 2018).

Stone, J., Ferrara, L., Kamrath, J., Getrajdman, J., Berkowitz, R., Moshier, E., Eddleman, K. (2008). Contemporary outcomes with the latest 1000 cases of multifetal pregnancy reduction (MPR). American Journal of Obstetrics \& Gynecology 199(4): 406e1-406e4.

Stotland, N. L. \& Shrestha, A. D. (2018). More Evidence That Abortion Is Not Associated With Increased Risk of Mental Illness. JAMA Psychiatry 75(8): 775-776. https://doi.org/10.1001/jamapsychiatry.2018.0838

Sundhedsloven. (2005). Afsnit VII Svangerskabsafbrydelse og fosterreduktion kap. 25 og 26. https://www.retsinformation.dk/ Forms/R0710.aspx? $\mathrm{id}=183932 \#$ id6d84f65b-675e-402bb7b7-96d6877c0513) (Accessed 12 February 2018).

Sørvig, Ø.S. (2017). Jeg var abortmotstander i ett år. Minerva. https://www.minervanett.no/jeg-var-abortmotstander-ett-ar/ November 2018).

The New York Times. (2013). Abortion restrictions in states. http://www.nytimes.com/interactive/2013/06/18/us/politics/abortionrestrictions.html (Accessed 28 February 2018).

Warren, M. A. (1973). On the moral and legal status of abortion. The Monist 57(1): 43-61. https://doi.org/10.5840/monist197357133

Woollard, F. (2016). Motherhood and Mistakes about Defeasible Duties to Benefit. Philosophy and Phenomenological Research 97(1): 126-149. https://doi.org/10.1111/phpr.12355

World Health Organization. (1946). Constitution of WHO: Principles. http://www.who.int/about/mission/en/ (Accessed 18 March 2018).

Zemet, R., Haas, J., Bart, Y., Barzilay, E, Zloto, K., Hershenson, R. (...) Lipitz, S. 2018. 133: Pregnancy outcome after multifetal pregnancy reduction of triplets to twins versus reduction to singleton American Journal of Obstetrics \& Gynecology, 218(1):94. https://doi.org/10.1016/j.ajog.2017. 10.110

Østborg, T.B. (2016). Prinsipper og følelser om fosterreduksjon. Dagens Medisin. https://www.dagensmedisin.no/artikler/2016/03/04/prinsipper-ogfolelser-om-fosterreduksjon/ (Accessed 15 November 2018). 
